\title{
Insecticide Resistant Natural Enemies and their Role in IPM
}

\author{
Shahida Ibrahim*, Ramandeep Kour, Shalini Aryan and Nadeya Khaliq
}

Shere Kashmir University of Agricultural Sciences and Technology of Jammu, India

*Corresponding author

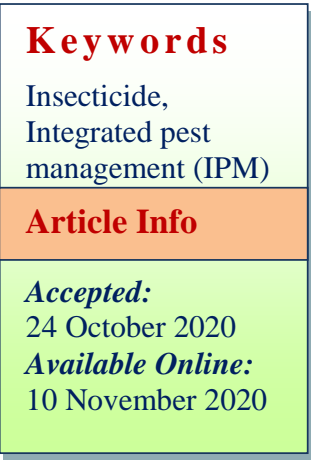

\section{A B S T R A C T}

\begin{abstract}
Resistance is the genetic ability of some individuals in an arthropod pest population to survive an application or multiple applications of a pesticide. In other words, the pesticide no longer effectively kills a sufficient number of individuals in the arthropod pest population. Resistance develops at the population level and is an inherited trait. As such, surviving arthropod pests can pass traits genetically onto their offspring or next generation, enriching the gene pool with resistant genes (alleles). The amount of "selection pressure," or the frequency of applying pesticides, is the main factor that influences the ability of an arthropod pest population to develop resistance to pesticides. This then increases the proportion or frequency of resistant individuals. Pesticide resistance in pests has severe negative consequences but can be used as a positive trait for natural enemies as an opportunity to improve the simultaneous use of two very valuable tools in pest management: chemical and biological control. Biological control adoption is limited in some areas, crops, or seasons due to the imperative use of pesticides needed to control diseases and pests. Most studies on pesticides and natural enemies try to establish the degree of compatibility using only a population, not considering the natural variation in insecticide susceptibility. However, there is variation in the response to pesticides among populations of a beneficial species, similarly to the response in any pest species. Knowledge of the natural and potential variation in the tolerance of natural enemies to pesticides may improve the design of robust IPM strategies by extending the role of biological control in some agricultural systems and by increasing the number of available compounds to control diseases and key, secondary, and invasive pests. There are a number of excellent revisions on pesticide resistance in natural enemies. In the present review, new cases of insecticide resistance in natural enemies are discussed, as a better understanding of pesticide resistance in natural enemies will allow us to enhance the integration of chemical and biological tools in IPM programs this time period.
\end{abstract}

\section{Introduction}

Insect pest problems in agriculture have shown a considerable shift during first decade of twenty-first century due to ecosystem and technological changes. In India, the crop losses have declined from 23.3 per cent in post-green revolution era to 17.5 per cent at present (Dhaliwal et al., 2010). Biological control has been accepted as an effective, environmentally non-degrading, technically appropriate, economically viable and socially acceptable method of pest management. It aims at suppression of insect pests of crops or other harmful organisms by using their natural enemies (parasites, predators and pathogens). It constitutes a deliberate attempt to use natural enemies, either by introducing new species or by increasing the effectiveness of the same those present already in the 
environment (Sankaran, 1986). In India the earliest and successful introduction of a natural enemy against an insect pest was the coccinellid beetle Cryptolaemus montrouzieri (Muls.) from Australia in 1898 (Rao et al., 1971). Now a day, application of different pesticides may depress populations of beneficial insects as well as target pests. Recent research has shown that pesticideresistant parasites selected in the laboratory can be established in the field and enhance IPM programs. Both laboratory selected or genetically engineered natural enemies may someday play an expanded role in IPM programs and the reduction of pesticide use.

Genetic manipulation of natural enemies of insect pests offers promise of enhancing their efficacy in agricultural cropping systems. Genetic improvement projects with natural enemies of insects have been conducted for

Improved climatic tolerances

Improved host finding ability

Changes in host preference

Improved synchronization with the host

Insecticide resistance

Non-diapause

Induction of thelytokous reproduction

However, there are sometimes inquires or issues regarding why pesticide resistance is rare or occurs less often in natural enemies (e.g., parasitoids and predators) in comparison to arthropod pests. There are two hypotheses that may possibly explain this phenomenon: 1) the food limitation and 2) pre-adaptation hypotheses.

\section{Food limitation hypothesis}

The food limitation hypothesis proposes that natural enemies tend to not readily develop or evolve resistance because pesticide applications, depending on frequency, reduce their food supply by killing susceptible prey. After applying pesticides, natural enemy populations tend to rebound at a slower rate in response to the lack of food, whereas insect and mite pests recover quickly in the absence of natural enemies. This is associated with a low density of prey, which results in natural enemies being negatively impacted in terms of consumption rates, fecundity and survival.

\section{Pre-adaptation hypothesis}

The pre-adaptation hypothesis advances the notion that herbivores or plant-feeding insects and mites are already pre-adapted to detoxify pesticides because they have evolved the ability to detoxify plant defensive compounds (e.g., secondary plant metabolites) such as plant alkaloids. Because plant-feeding insects and mites are typically exposed to a broad diversity of plants and thus plant allelochemicals (non-nutritional chemicals synthesized by an organism that affect growth, survival and behaviour of certain member species), they are able to metabolize a broad range of chemical defences by producing inducible enzymes in response to particular enzymes associated with specific compounds.

\section{Emerging technologies in augmentation of natural enemies}

As in crop breeding, three potential genetic manipulation tactics are being utilised for achieving the above goals.
a. Artificial selection
b. Hybridization or, use of Heterosis
c. Use of Biotechnology (recombinant DNA (rDNA)
techniques)

\section{Artificial selection}

Artificial selection of arthropod natural enemies for resistance to pesticides has been proposed as a method form improving the usefulness of natural enemies in integrated 
pest management programs (Roush and Hoy, 1981; Hoy, 1985).

\section{How does a resistant population come into existence}

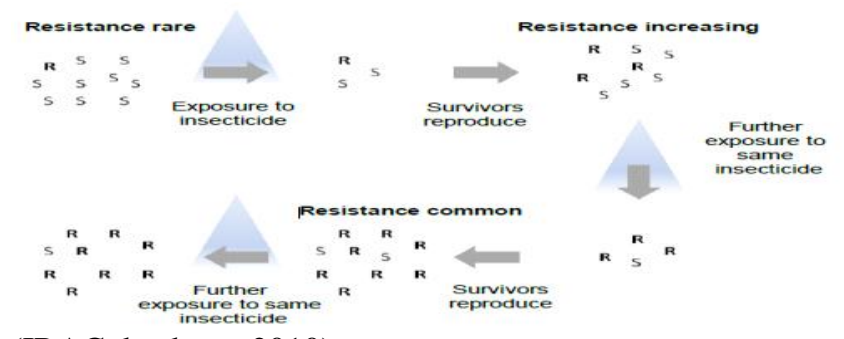

(IRAC database, 2010)

Pesticide resistance is a genetically based phenomenon. Resistance occurs when an insect population - insects, for instance - is exposed to a pesticide. When this happens, not all insects are killed. Those individuals that survive frequently have done so because they are genetically predisposed to be resistant to the pesticide. Repeated applications and higher rates of the insecticide will kill increasing numbers of individuals, but some resistant insects will survive. The offspring of these survivors will carry the genetic makeup of their parents. These offspring, many of which will inherit the ability to survive the exposure to the insecticide, will become a greater proportion with each succeeding generation of the population. Because of the rapid reproductive rate of many insects - a generation of many insects can take place in a few weeks - many generations can be produced in a single season or year. It's easy to see that repeated applications of an insecticide will quickly eliminate all susceptible insects in the population, essentially selecting out those individuals that are resistant. In a short period the entire population of insects will be resistant. The more times a population is exposed to a pesticide, especially a broadspectrum pesticide, the more quickly resistance will develop.
This study was conducted in PDBC (Project Directorate of Biological Control) Bangalore by Jalali and his coworkers in 2005 in Trichogramma chilonis against Endosulfan. The doses were increased during each successive generation of selection. The selection was initiated at a dose of $0.004 \%$ which was gradually increased to $0.009 \%$. At lowest concentration the survival among tolerant strain $95 \%$ and parasitism is $100 \%$ as compared to susceptible strains having per cent survival only $10 \%$ and parasitism $40 \%$. At lower concentration parasitoids took $\leq 10$ 12 generations to develop resistance while at higher concentrations took 24-90 generations to develop resistance. In the susceptible population over $90 \%$ mortality and $10 \%$ parasitism was obtained at each concentration as compared to resistant strain of parasitoid (40\% mortality and $90 \%$ parasitism) after each successive generation of exposure to insecticide.

From LC50 value it is concluded that the resistant factor of tolerant strain was 15.1 folds and F1 cross were 8.53 folds over susceptible strain

An endosulfan tolerant strain of $T$. chilonis was developed and transferred to a private industry, which is marketing it under the name of 'Endogram'.

This experiment was conducted by Elizabeth E. Grafton-Cardwell and Marjorie A. Hoy in California during the year 1981 -1982. They collected adult C. carnea from alfalfa in San Joaquin, Fresno, Kern, and Imperial counties during 1981 and 1982 and maintained them as four separate colonies. Adults, larvae, and eggs were screened with the organophosphates diazinon (50 percent WP) and phosmet (Imidan, 50 percent WP), the carbamates carbaryl (Sevin, 50 percent WP) and methomyl (Lannate, WS liquid), and the pyrethroids permethrin (Ambush, Pounce, 
EC) and fenvalerate (Pydrin, EC). Adults were tested in petri dishes sprayed with a range of concentrations of formulated pesticide in water plus a wetting agent. Each dish containing five adult lacewings was closed with tissue paper, and adults were provided with food and water. Twenty adults were tested at each concentration, and mortality was assessed after 72 hours.

Selection for carbaryl resistance occurred very rapidly in this assay (Fig. 1). All San Joaquin County larvae died at rates above $\mathbf{0 . 0 0 3}$ pound active ingredient per 10 gallons. Of the unselected Imperial County larvae, 97 to 99 percent died at rates above 0.03 pound, but after only one selection (carbaryl-1), mortality decreased to approximately 90 percent at these rates. Mortality decreased to 50 to 70 percent after the second round of selection (carbaryl-2) and to less than 20 percent after four rounds of selection. Up to 80 percent of the selected lacewing larvae survived on formulated material at the field rate recommended for alfalfa (approximately 1.5 pounds active ingredient per 10 gallons), compared with only 3 percent of the unselected strain.

\section{Hybridization}

Different local strains from various agroclimatic regions were collected and interbreeding was carried.

Hybridization results in heterosis and heterobeltiosis in the offsprings.

Patil and Yadav (1999) studied estimates of heterosis and heterobeltiosis for some important traits of hybrids of Corcyra carnea.

This experiment was conducted by Hidesh Naka and co-workers in Japan. Chrysoperla carnea was introduced from Germany and Chrysoperla nipponensis was indigenous from Japan. Adult $C$. nipponensis were collected from NIAES (Tsukuba, Japan) fields. C. carnea larvae (Kagetaro) were purchased from Arysta LifeScience (Tokyo, Japan). The two species were reared in a similar manner. Approximately 50 females and 50 males were maintained in a 30 by 30 by $30-\mathrm{cm}$ cage, supplied with water and a honey-yeast diet (a mixture of water, honey, and yeast extract as 10:10:3 mass ratio, respectively) and applied to absorbent cotton according to a modified version of the method of Henry (1979). Larvae were individually reared by supplying _20 mg of Entofood (frozen eggs of Ephestia kuehniella; Arysta Life- Science) every 2 d. Rearing and experiments were conducted under conditions of $16 \mathrm{~L}: 8 \mathrm{D}$ at $25^{\circ} \mathrm{C}$. Crosses were carried out with one pair of 7-14 days old virgin adults, kept in a plastic cup (75 $\mathrm{mm}$ diameter by 45mmheight, $100 \mathrm{ml}$ ), supplied with water and a honey-yeast diet. There were 30 replicates each of parental conspecific crosses, $C$. carnea $\times C$. Carnea and $C$. nipponensis $\times \quad C$. nipponensis, and 63 replicates of interspecific crosses, $C$. Carnea females $\times C$. Nipponensis males and $C$. nipponensis females $\times C$. Carnea males. Interspecific offspring (F1) were reared individually and supplied with Entofood, and emerged adults were crossed with each other or backcrossed to their parent species.

The designed F1 cross experiment to obtain an equal and maximal number of replicates using emerged F1 adults; consequently, we could ensure that all crosses of F1 adults were replicated by five pairs. Reproductive potential, fertility rate or the number of offspring, seeds or spores per "parent", has a significant effect on the development of resistance in insect populations. For all sexually reproductive insects that are targeted by pesticides, and with other factors being equal, the greater the number of offspring per organism, the larger the number of resistant individuals there will be. 
The reason for this in insects is that producing a large number of offspring increases the chances of there being more individuals carrying the resistance gene and hence, if pesticide use continues, the odds of selecting individuals that carry one or two resistant alleles. The larger the number of survivors carrying resistance genes, the greater the potential is for heterozygote or homozygote individuals to mate. This can result in an increase in the frequency of the resistance genes in the population. The cross between $\mathrm{c} \times \mathrm{n}$ shows higher fertility percentage $(90 \%)$ (Table 1-6).

\section{Recombinant DNA techniques}

Recombinant DNA technology, joining together of DNA molecules from two different species that are inserted into a host organism to produce new genetic combinations that are of value to science, medicine, agriculture, and industry.

Since the focus of all genetics is the gene, the fundamental goal of laboratory geneticists is to isolate, characterize, and manipulate genes. Although it is relatively easy to isolate a sample of DNA from a collection of cells, finding a specific gene within this DNA sample can be compared to finding a needle in a haystack.

\section{Advantages of biotechnological approaches over artificial selection}

The use of genetic engineering methods for the improvement of beneficial arthropods has two advantages over artificial selection:

The goal of genetic improvement can be achieved rapidly, without the generations of rearing required for classical selection protocols

Rather than selecting solely from the available gene pool of the arthropod natural enemy, any gene from any species can be used, in principle, for genetic improvement

\section{Processes of developing genetically modified natural enemy}

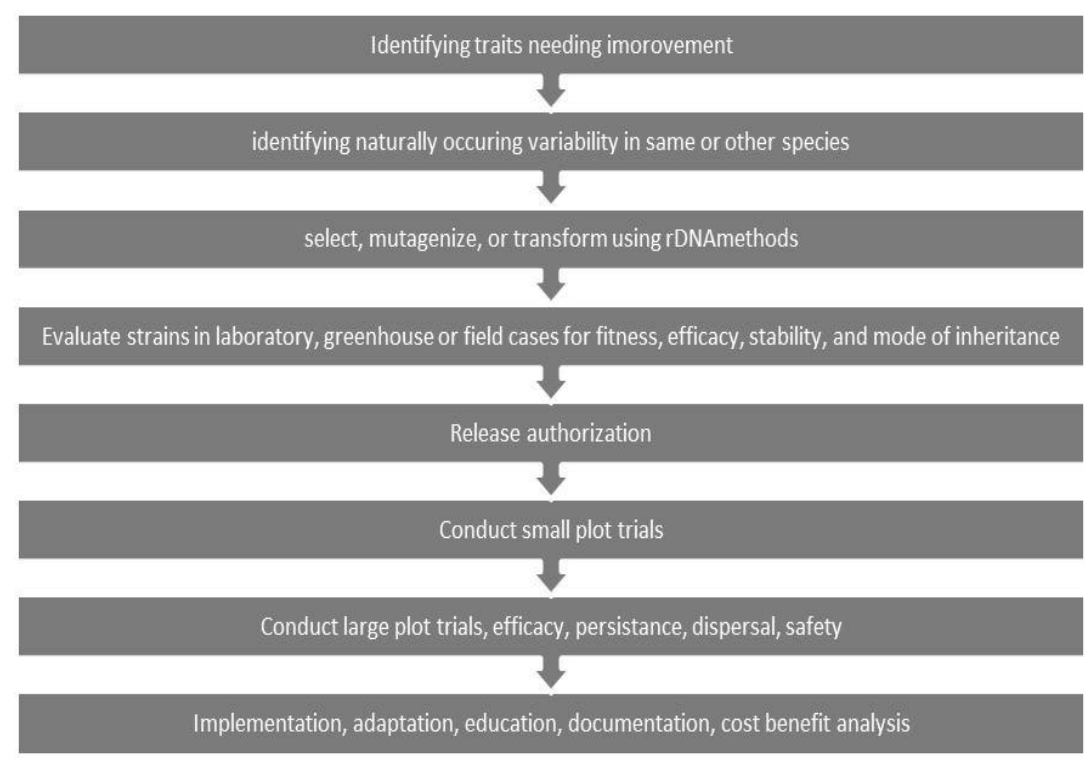

What is involved in recombination DNA techniques..........?

It involves various steps
Knowledge of biology, ecology and behaviour of target species

Identifying traits to be altered 
Suitable gene must be identified, cloned and insert into insect genome.

What germ-line transformation methods are available.........?

Inserting cloned DNA into insect can be accomplished by:

Transposable element vectors

Paratransgenesis

Viral vectors

\section{Transposable element vectors}

A transposable element (TE or transposon) is a DNA sequence that can change its position within a genome, sometimes creating or reversing mutations and altering the cell's genetic identity and genome size. Transposition often results in duplication of the TE. Barbara McClintock's discovery of these jumping genes earned her a Nobel Prize in 1983. Transposable elements are used as vectors for the transfer of foreign DNA into host. While all the transformation vectors currently used for non-drosophilid germ-line transformation are Class II transposable elements that share common elements in terms of structure and mechanism of movement, significant differences exist among them and thus they must be considered independently when assessing risk.

A primary consideration is that these transposons, along with other mobile genetic elements, are mutagenic by virtue of their ability to integrate into coding and noncoding genomic DNA sequences. Thus, they have the potential to disrupt normal gene function resulting in costs to fitness. On the other hand, a large percentage of most genomes are comprised of such mobile elements, and various mechanisms either have pre-existed or have evolved to regulate transposon function. A major concern relates to how a genome interacts with a transposonbased vector that has been newly introduced. Each of the currently available Class II transposon-based vector systems are reviewed below and some of their key characteristics are highlighted.

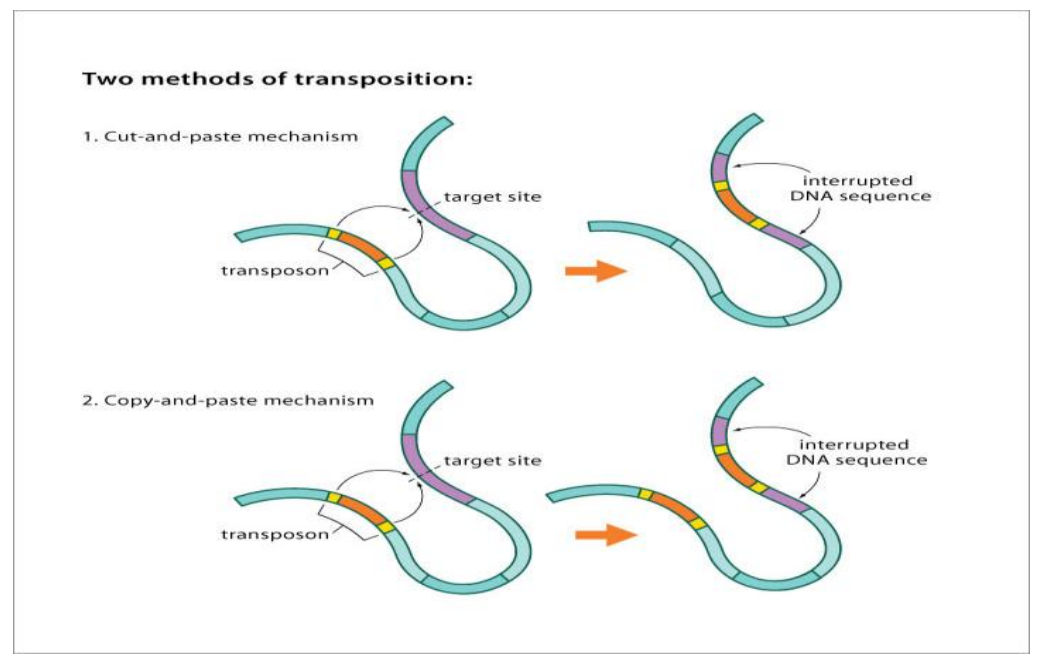

\section{Paratransgenesis}

Genetic alteration of microbes living in association with insects for various purposes The symbionts are passed through generations by transovariole transfer

The two bacterial endosymbionts Wolbachia sp. (Gram negative)and Rhodococcus sp. (Gram positive) are commonly employed 


\section{Viral vectors}

Viruses are modified to as vectors in insects and insect cell (Burns, 2000)

Baculovirus vectors

Densonucleosis virus vector

Polydna viral vector

Retroviral vector

\section{Baculovirus vectors}

Baculovirus expression systems have found increasing applications for the production of eukaryotic biologically active proteins. The system is similar to mammalian cells, in that it exhibits posttranslational processing folding, disulfide formation, glycosylation, phosphorylation, and signal peptide cleavage. The system utilizes the baculovirus, Autographa californica multiple nuclear polyhedrosis virus (AcMNPV), which infects many species of Lepidoteran insects. The insect cells used in most laboratory experiments are derived from cultured ovarian cells of Spodopterafrugiperda (Fig. 2 and 3).

\section{Baculovirus Transfer Vector}

In practice, AcMNPV genome is too large $(128 \mathrm{~kb})$ to work with. A baculovirus transfer vector has to be constructed for cloning use. Transfer vectors contain: (1) a $\sim 7 \mathrm{~kb}$ fragment of AcMNPV carrying the polyphedrin gene, and (2) a multiple cloning site constructed downstream of the polyhedrin gene promoter The gene of interest is to be inserted in the MCS. Both the recombinant transfer vector DNA and wild-type viral DNA are used to transfect insect cells. Within the cell, the inserted gene sequence is transferred to the AcMNPV viral DNA by homologous recombination forming the recombinant baculovirus DNA.

Since insertion of a foreign gene at the MCS downstream of the polyhedrin gene promoter causes inactivation of the polyhedron gene, cells carrying the recombinant baculovirus will be occlusion negative, visually distinguishable from cells containing occlusion positive wildtype virus.

The frequency of recombination by this technique is less than $1 \%$, and occlusionnegative plaques are frequently obscured among the high background of wild-type (occlusionpositive) plaques.

\section{Retroviral vector}

Retroviruses are RNA viruses that replicate via a ds-DNA intermediate. The infection cycle begins with the interaction between viral envelope and the host cell's plasma membrane, delivering the particle into the cell. The capsid contains two copies of the RNA genome, as well as reverse transcriptase/integrase.

After infection, the RNA genome is reverse transcribed to produce a cDNA copy, a DNA intermediate, which integrates into the genome randomly. Retroviruses contain RNA as the genetic material in a protein core enclosed by an outer envelop.

The viral RNA genome contains at the 5' and 3 ' ends, long terminal repeats (LTR) carrying the transcriptional initiation and termination, respectively. In between the 5' and 3' LTR regions, are three coding regions for viral proteins ( $g a g$ for viral core proteins, pol for the enzyme reverse transcriptase, and env for the envelop), and a psi ( $(/ /)$ region carrying signals for directing the assembly of RNA in forming virus particles.

\section{Retrovirus Vector and Packaging Cell}

Retroviruses cannot be used directly as vectors because they are infectious. Safe retrovirus vectors are constructed using a system consisting of two components: (1) 
retrovirus vector, and (2) packaging cell.

A retrovirus vector is a recombinant plasmid carrying a sequence of the viral genome (Fig. 4). In the construction of viral vector, most of the viral structural genes are deleted, but the LTR and psi $(Y /)$ region are retained. The viral sequence is constructed with selective markers, such as the neo gene (karamycin resistance), or hyg gene (hygromycin resistance).

The retrovirus LTR (long terminal repeats) strong promoter is usually used for the expression of inserted gene. Other promoters such as simian virus 40 (SV40) early promoter can also be used. A second promoter is used to control the expression of selective markers. A unique restriction site is constructed for insertion of foreign DNA

\section{Methods of genetic transformation of Arthropods}

\section{Electroporation}

Electroporation is a mechanical method used for the introduction of polar molecules into a host cell through the cell membrane.

This method was first demonstrated by Wong and Neumann in 1982 to study gene transfer in mouse cells.

It is now a widely used method for the introduction of transgene either stably or transiently into bacterial, fungal, plant and animal cells.

It involves use of a large electric pulse that temporarily disturbs the phospholipid bilayer, allowing the passage of molecules such as DNA (Fig. 5).

\section{Advantages}

It is highly versatile and effective for nearly all cell types and species.

It is highly efficient method as majority of cells take in the target DNA molecule.

It can be performed at a small scale and only a small amount of DNA is required as compared to other methods.

\section{Disadvantages}

Cell damage is one of the limitations of this method caused by irregular intensity pulses resulting in too large pores which fail to close after membrane discharge.

Another limitation is the non-specific transport which may result in an ion imbalance causing improper cell function and cell death.

\section{Microinjection of egg}

DNA microinjection was first proposed by Dr. Marshall A. Barber in the early of nineteenth century.

This method is widely used for gene transfection in mammals.

It involves delivery of foreign DNA into a living cell (e.g. a cell, egg, oocyte, embryos of animals) through a fine glass micropipette. The introduced DNA may lead to the over or under expression of certain genes.

It is used to identify the characteristic function of dominant genes (Fig. 6).

\section{Advantages}

No requirement of a marker gene.

Introduction of the target gene directly into a single cell. 
Easy identification of transformed cells upon injection of dye along with the DNA.

No requirement of selection of the transformed cells using antibiotic resistance or herbicide resistance markers.

It can be used for creating transgenic organisms, particularly mammals.

Table.1 Artificial selection of arthropod natural enemies for resistance to pesticides

\begin{tabular}{|l|l|l|}
\hline \multicolumn{1}{|c|}{ Natural enemy } & \multicolumn{1}{|c|}{ Insecticide } & \multicolumn{1}{c|}{ References } \\
\hline Trichogramma chilonis & Endosulfan & Jalali et al., 2006. \\
\hline Trichogramma chilonis & $\begin{array}{l}\text { Multiple-pesticide (endosulfan,spinosad and lamda } \\
\text { cyhalothrin) }\end{array}$ & Charles et al. ,2011 \\
\hline Chrysoperla carnea & Monocrotophos & Patel and Yadav, 1995 \\
\hline Trioxys pallidus & Azinphosmethyl & Spollen and Hoy ,1992 \\
\hline Metaseialus occidentalis & Carbaryl an permethrin. & Hoy, 1984 \\
\hline Aphytis melinus & Carbaryl & Spollen and Hoy ,1992 \\
\hline Macrocentrus ancylivorus & DDT & Pielou and Glasser, 1951 \\
\hline
\end{tabular}

Routray et al., 2016

Table.2 Development of endosulfan tolerant strain of an egg parasitoid Trichogramma chilonis Ishii (Hymenoptera:Trichogrammatidae)

\begin{tabular}{|l|c|c|c|c|c|}
\hline \multirow{2}{*}{$\begin{array}{l}\text { Concentration } \\
\text { \% }\end{array}$} & \multirow{2}{*}{$\begin{array}{c}\text { Generation } \\
\text { reared at each } \\
\text { dosage level }\end{array}$} & \multicolumn{2}{|c|}{$\begin{array}{c}\text { Adult survival (\%) } \\
\text { (after } \mathbf{6 h r} \text { of exposure) }\end{array}$} & \multicolumn{2}{|c|}{ Parasitisation (\%) } \\
\cline { 3 - 6 } & T strain & S strain & T strain & S strain \\
\hline $\mathbf{0 . 0 0 4}$ & 1 & 95 & 10 & 100 & 40 \\
\hline $\mathbf{0 . 0 0 9}$ & 14 & 98 & 5 & 100 & 15 \\
\hline $\mathbf{0 . 0 1 8}$ & 27 & 80 & 4 & 100 & 10 \\
\hline $\mathbf{0 . 0 2 6}$ & 41 & 70 & 2 & 93 & 5 \\
\hline $\mathbf{0 . 0 3 5}$ & 73 & 50 & 2 & 100 & 5 \\
\hline $\mathbf{0 . 0 4 4}$ & 164 & 50 & 4 & 100 & 0 \\
\hline $\mathbf{0 . 0 5 3}$ & 196 & 30 & 6 & 100 & 0 \\
\hline $\mathbf{0 . 0 6 1}$ & 221 & 50 & 9 & 95 & 4 \\
\hline $\mathbf{0 . 0 7}$ & 255 & 80 & 7 & 95 & 2 \\
\hline $\mathbf{0 . 0 9}$ & 341 & 85 & 6 & 90 & 6 \\
\hline
\end{tabular}

Table.3 Median lethal concentration (LC50) of tolerant and susceptible strain of Trichogramma chilonis

\begin{tabular}{|l|l|}
\hline Strain & LC50 $(\mathbf{p p m})$ \\
\hline Tolerant & 1074.96 \\
\hline Susceptible & 70.91 \\
\hline F1 cross & 604.96 \\
\hline
\end{tabular}


Fig.1 Selection of common green lacewing for resistance to carbaryl

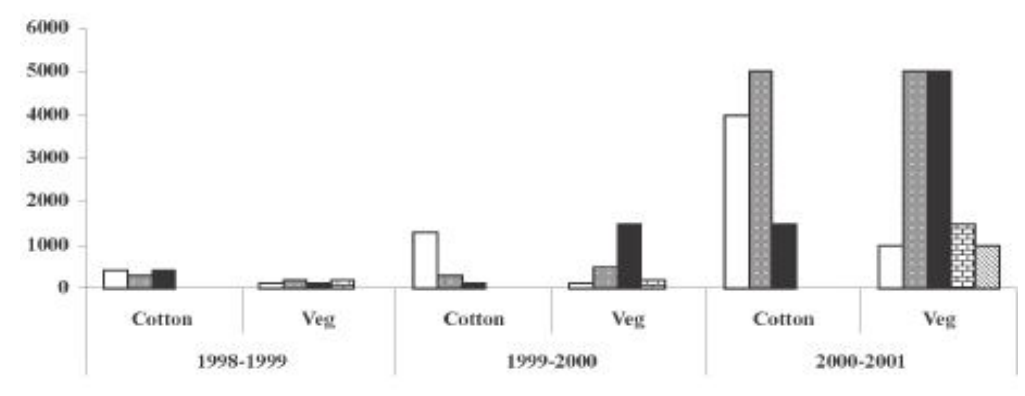

口Gujarat घMadhya Pradesh EAndhra Pradesh gMaharashtra @Orissa/ West Bengal

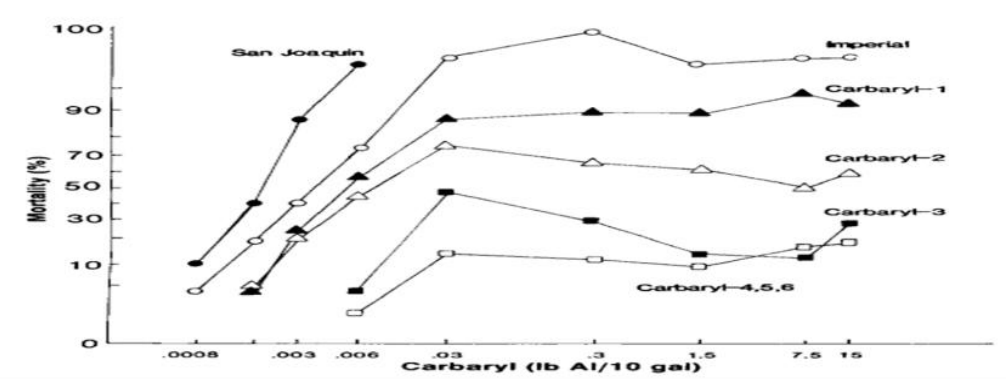

Fig.2 Structural organization of a baculovirus transfer vector

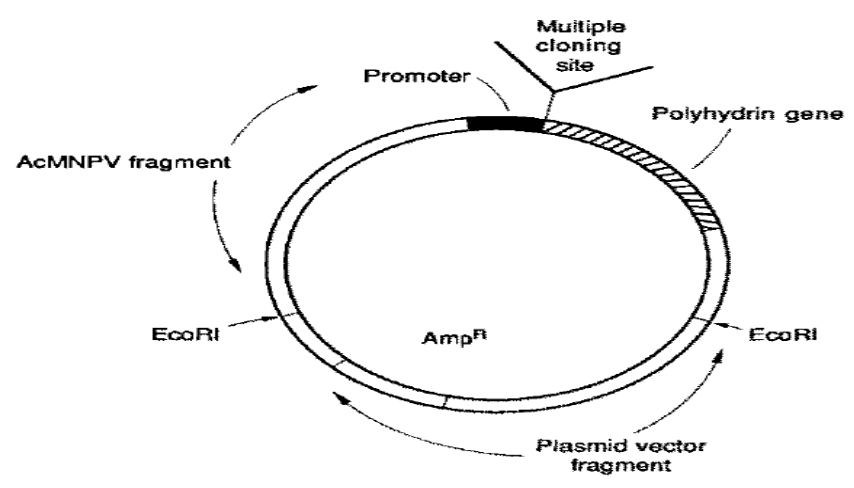

Table.4 Laboratory hybridization between the introduced and indigenous green lacewing in Japan

\begin{tabular}{|c|c|c|c|}
\hline & Cross & Fertility & Mortality \\
\hline Female & Male & $\%$ & $\%$ \\
\hline & $\mathbf{n} \times \mathbf{n}$ & 9.5 & 82 \\
\hline $\mathbf{c} \times \mathbf{c}$ & 41.3 & 68 \\
\hline $\mathbf{c} \times \mathbf{n}$ & 90.0 & 14 \\
\hline $\mathbf{n} \times \mathbf{c}$ & $\mathbf{7 0 . 0}$ & $\mathbf{2 5}$ \\
\hline
\end{tabular}

$\mathrm{n}$ : Chrysoperla nipponensis

C: Chrysoperla carnea 
Table.5 Novel Genes Cloned for Genetic Manipulation of natural enemies

\begin{tabular}{|c|c|c|}
\hline S.NO. & Gene of interest & Species \\
\hline 1 & $\begin{array}{l}\text { Acetylcholinesterase (Ace)_pesticide } \\
\text { resistance }\end{array}$ & Anopheles stephensi \\
\hline 2 & $\begin{array}{l}\text { Parathion hydrolase (opd) _ parathion } \\
\text { resistance }\end{array}$ & $\begin{array}{l}\text { Cardiochiles diaphaniae } \\
\text { Spodoptera frugiperda }\end{array}$ \\
\hline 3 & $\begin{array}{l}\text { Esterase b1 amplification core- } \\
\text { organophosphate resistance }\end{array}$ & $\begin{array}{l}\text { Drosophila melanogaster } \\
\text { Culex species }\end{array}$ \\
\hline 4 & $\begin{array}{l}\text { Glutathione } S \text {-transferase (MdGST1)- } \\
\text { organohosphate resistance }\end{array}$ & Musca domestica \\
\hline 5 & g-Aminobutyric acid A $(G A B A A)$ - dieldrin resistance & Drosophila \\
\hline 6 & Cytochrome $(P 450-B a)-D D T$ resistance & Drosophila \\
\hline 7 & $\begin{array}{l}\text { Glutathione } S \text {-transferase (DmGST1-1)- } \\
\text { DDT resistance }\end{array}$ & Drosophila \\
\hline 8 & $\begin{array}{l}\text { Metallothionein genes }(\mathrm{Mtn}) \text { —copper } \\
\text { resistance }\end{array}$ & Drosophila \\
\hline 9 & Multidrug resistance (Mdr49 and Mdr65) _ colchicine resistance & Drosophila \\
\hline 10 & b-tubulin genes -Benomyl resistance & Neurospora crassa and Septoria nodorum \\
\hline 11 & Knockdown resistance : kdr; DDT and Pyrethroid & Musca domestica \\
\hline
\end{tabular}

Biotechnological approaches in pest management by H. C. Sharma, 2009

Table.6 Insecticide resistance of field and stored grain population of natural enemies

\begin{tabular}{|c|c|c|}
\hline Species & Location & Insecticides \\
\hline Amblyseius fallacis & Michigan,New York & $\begin{array}{l}\text { Azinphosmethyl, Permethrin,Carbaryl, DDT, } \\
\text { Dimethoate }\end{array}$ \\
\hline Amblyseius hibisci & California & Dimethoate \\
\hline Metaseiulus occidentalis & California & Dimethoate ,Methomyl, Diazinon, Azinphosmethyl, \\
\hline Typhlodronus arboreus & Oregon & Azinphosmethyl, Carbaryl \\
\hline Typhlodronus pyri & $\begin{array}{l}\text { England, Netherland, } \\
\text { New Zealand }\end{array}$ & $\begin{array}{l}\text { Azinphosmethyl, Carbaryl } \\
\text { Permethrin }\end{array}$ \\
\hline Chiracanthium mildei & Israel & Malathion \\
\hline Xylocoris flavipes & South Carolina & Malathion \\
\hline Aphidoletes aphidimyza & Michigan & Azinphosmethyl \\
\hline Anisopteromalus calandrae & South Carolina & $\begin{array}{l}\text { Chlorpyriphos methyl,Malathion,Cyfluthrin, } \\
\text { Deltamethrin }\end{array}$ \\
\hline Aphytis africanus & South Africa & Methidathion \\
\hline Aphytis holoxanthus & Israel & Malathion \\
\hline Aphytis melinus & California & $\begin{array}{l}\text { Carbaryl, Chlorpyriphos, } \\
\text { Dimethoate, Malathion, }\end{array}$ \\
\hline Bracon hebetor & Georgia & Malathion \\
\hline Comperiella bifasciata & South Africa & Methidathion \\
\hline $\begin{array}{l}\text { Diaretiella rapae } \\
\text { Diglyphus begini }\end{array}$ & $\begin{array}{l}\text { California } \\
\text { Hawaii }\end{array}$ & $\begin{array}{l}\text { Methomyl } \\
\text { Fanvalerate,Methomyl,Oxamyl,Permethrin }\end{array}$ \\
\hline Ganaspidium utilis & Hawaii & $\begin{array}{l}\text { Fanvalerate, Malathion, Methomyl, Oxamyl, } \\
\text { Permethrin }\end{array}$ \\
\hline Pholetesor ornigis & Canada & Azinphosmethyl, Fenvalerate, Methomyl, Permethrin \\
\hline Trioxys pallidus & California & Azinphosmethyl, \\
\hline Chrysoperla carnea & California & Carbaryl,Diazinon,Fenvalerate,Methomyl,Permethrin \\
\hline
\end{tabular}

Tabashink \& Johnson, 2014 
Fig.3 Cloning strategy using a baculovirus transfer vector

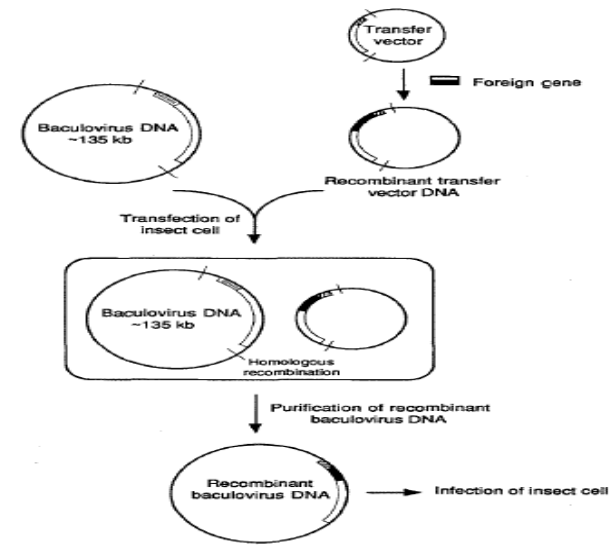

Fig.4 Structural organization of retrovirus vector

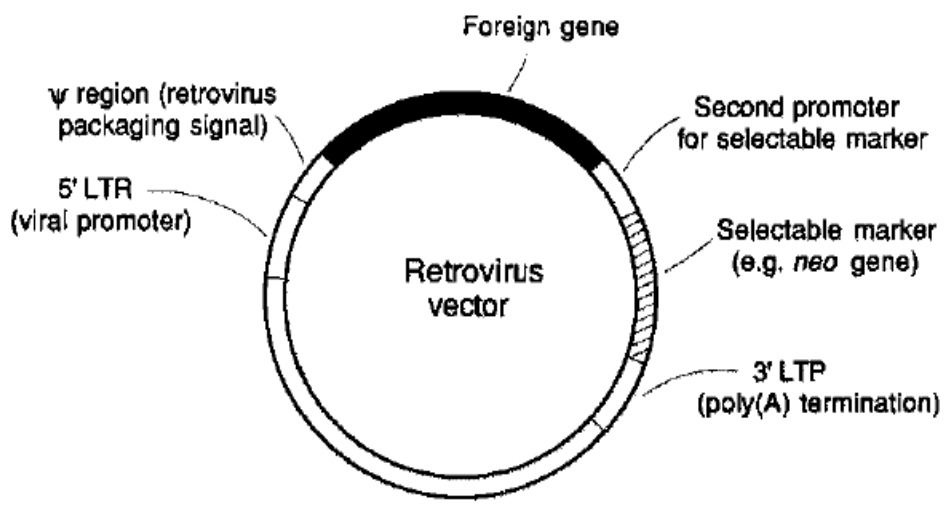

Fig.5 Electroporation system

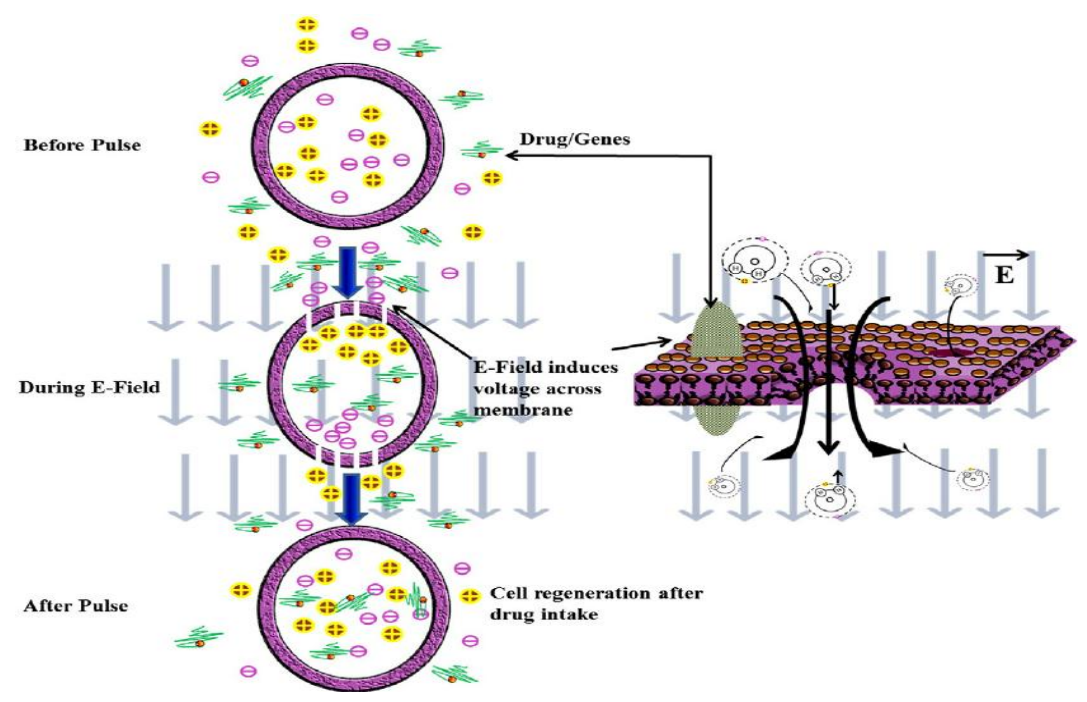


Fig.6 Microinjection of egg

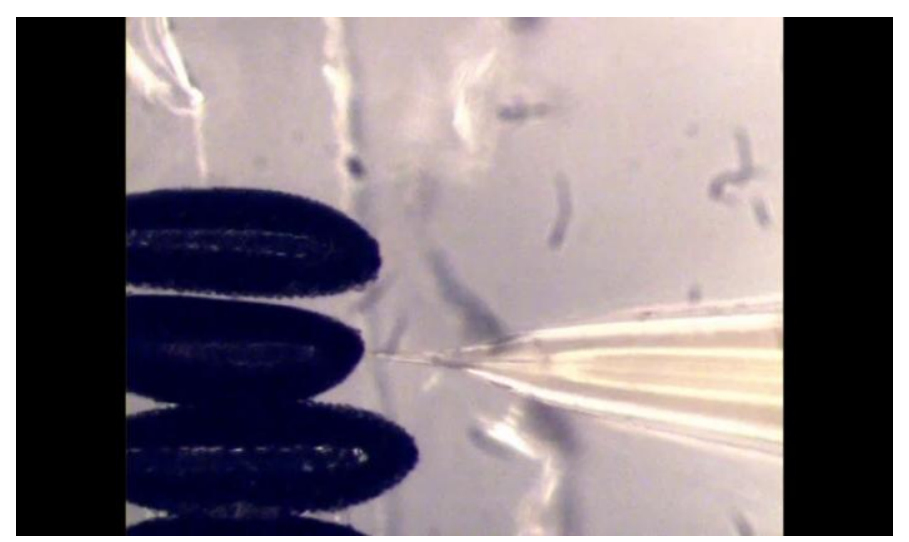

Fig.7 Maternal microinjection

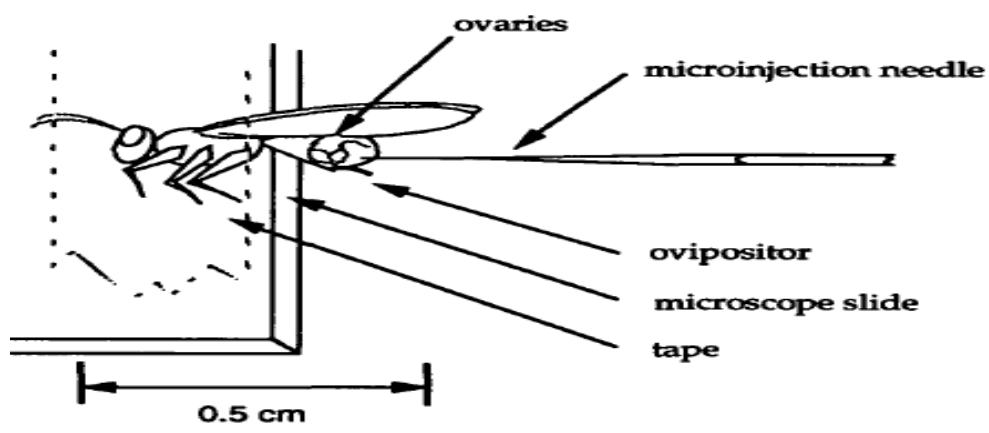

Fig.8 Microprojectile system

Figure 3. The Biolistic ${ }^{\mathrm{TM}}$ microprojectile gun
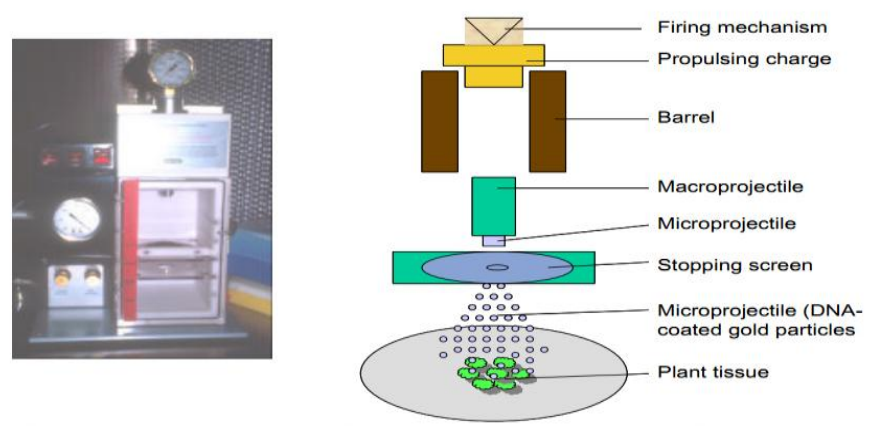

\section{Maternal microinjection}

One DNA delivery system that shows promise is maternal microinjection (Presnail and Hoy 1992). DNA is injected into, or near, the arthropod ovary with the aim of transmitting injected DNA to several eggs.
Maternal microinjection was 1st investigated in the phytoseiid mite Metaseiulus (=Galendromus or Typhlodromus) occidentalis (Nesbitt) (Presnail and Hoy 1992). The utility of the method was later examined in a $2^{\text {nd }}$ phytoseiid, Amblyseius jinlandicus (Oudemans). In both species, 
injected DNA was transmitted to multiple eggs within the injected female during a period of several days. It has been possible to isolate transformants from the progeny of as few as 20 injected phytoseiid females. The method has not yet been tested in an insect (Fig. 7).

\section{Particle bombardment / Micro projectile}

Prof Sanford and colleagues at Cornell University (USA) developed the original bombardment concept in 1987 and coined the term "biolistics" (short for "biological ballistics") for both the process and the device (Fig. 8).

Also termed as particle bombardment, particle gun, micro projectile bombardment and particle acceleration.

It employs high-velocity micro projectiles to deliver substances into cells and tissues.

\section{Advantages}

Simple and convenient method involving coating DNA or RNA on to gold microcarrier, loading sample cartridges, pointing the nozzle and firing the device.

No need to obtain protoplast as the intact cell wall can be penetrated.

Manipulation of genome of sub-cellular organelles can be done.

Eliminates the use of potentially harmful viruses or toxic chemical treatment as gene delivery vehicle.

This device offers to place DNA or RNA exactly where it is needed into any organism.

\section{Disadvantages}

The transformation efficiency may be lower than Agrobacterium- mediated transformation.

Specialized equipment is needed. Moreover the device and consumables are costly.

Associated cell damage can occur.

The target tissue should have regeneration capacity.

Random integration is also a concern.

Chances of multiple copy insertions could cause gene silencing.

\section{What Causes Insecticide Resistance?}

\section{Mechanisms}

\section{Biochemical / metabolic resistance}

Cytochrome $\mathrm{P}_{-450}$ dependant monooxygenase Hydrolase

Glutathione-S-Transferases

\section{Physiological resistance}

Reduced neuronal sensitivity to insecticides Altered target-site resistance

Decreased penetration of the insecticide through the body wall

Increased excretion or sequestration of insecticides

\section{Behavioural resistance}

Biochemical/metabolic resistance: Resistant insects may detoxify or destroy the toxin faster than susceptible insects, or quickly rid their bodies of the toxic molecules. Metabolic resistance is the most common mechanism. This involves many molecular alterations:

Cytochrome $\quad \mathbf{P}_{-450}$ dependant monooxygenase: The $\mathrm{P} 450$ monooxygenases are ubiquitous enzymes, found from bacteria to mammals. They are involved indigenous 
metabolism as well as in the metabolism of xenobiotics. For example, in insects these activities are essential for the synthesis and the degradation of the steroid moulting hormones and juvenile hormones and also in the metabolism of pheromones.

The P450 enzymes are also important for the adaptative mechanisms of insects to the toxic chemicals synthesized by their host plants (Gould 1984). This adaptation is notable for the fact that the biosynthesis of these enzymes can be induced by the presence of the toxins in the food (Hung et al., 1995). P450 monooxygenase activities can be involved in the metabolism of virtually all insecticides, leading to an activation of the molecule or, more generally, to a detoxication (Agosin 1985).

For some insects, this detoxication is so active (Taylor and Feyereisen, 1996) that the insecticide does not reach its molecular target before being metabolized and degraded by these enzymes: such individuals are resistant to insecticides. P450 enzymes bind molecular oxygen and receive electrons from NADPH to introduce an oxygen atom into the substrate and to form water with the other oxygen atom according to the reaction:

\section{Substrate( $(S)+\mathrm{NADPH}+\mathrm{H}^{+}+\mathrm{O}_{2} \longrightarrow \mathrm{S}(0)+\mathrm{NADP}+\mathrm{H}_{2}^{+} \mathrm{O}$}

The electrons necessary for this reaction are transferred from nicotinamide-adenine dinucleotide phosphate (NADPH) on the substrate $\mathrm{P} 450$ complex by an NADPH cytochrome $\mathrm{P} 450$ reductase, but this reaction can also be stimulated by cytochrome b5 (Zhang \& Scott 1996). The stability of the initial product $[\mathrm{S}(\mathrm{O})]$ can vary, leading to overall reactions as diverse as hydroxylation, epoxidation, O-, N-, and S- dealkylations, $\mathrm{N}$ and $\mathrm{S}$ - oxidations and to such various chemical reactions, and products that these enzymes have been called 'diversozymes' (Coon et al., 1996). The key protein of this enzymatic system is in each case a cytochrome P450 that is responsible for the specicity of the reaction.

$$
\begin{aligned}
\mathrm{RH}+\mathrm{O}_{2}+\mathrm{NADPH}+\mathrm{H}^{+} & \\
& \rightarrow \mathrm{ROH}+\mathrm{H}_{2} \mathrm{O}+\mathrm{NADP}^{+}
\end{aligned}
$$

Hydrolases: They commonly initiate organophosphorus compounds degradation with special functional enzyme by cleaving $\mathrm{P}$ $\mathrm{O}$ or $\mathrm{P}-\mathrm{S}$ bond reaction, and these enzymes have a broad substrate range with a close similarity structure or a chemical functional group, and can hydrolyze a number of organo-phosphorus compounds. While one of these enzymes or some variant can allow the initial detoxification of an organophosphorus contaminant, the organism may not degrade the hydrolysis products, some of which are toxic and inhibit bacterial growth (Walker and Keasling, 2002).

The OPs are mainly detoxified through oxidation and hydrolysis. One of the most common metabolic resistance mechanisms is that of elevated levels, or activity, of esterase enzymes which hydrolyze ester bonds or sequester insecticides.

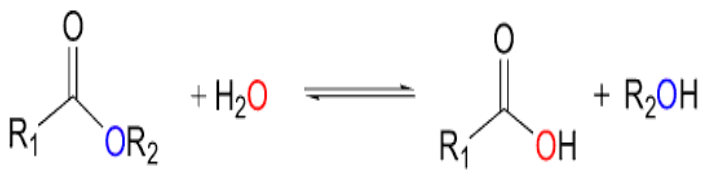

\section{Glutathione-S-Transferases}

Glutathione transferases (GSTs) are a diverse family of enzymes found ubiquitously in aerobic organisms. They play a central role in the detoxification of both endogenous and xenobiotic compounds and are also involved in intracellular transport, biosynthesis of hormones and protection against oxidative stress. 
Interest in insect GSTs has primarily focused on their role in insecticide resistance. GSTs can metabolize insecticides by facilitating their reductive dehydrochlorination or by conjugation reactions with reduced glutathione, to produce water-soluble metabolites that are more readily excreted. In addition, they contribute to the removal of toxic oxygen free radical species produced through the action of pesticides

\section{Physiological resistance}

Resistant insects reduce toxicity through changes in basic physiology. The chemical is not broken down to less toxic form, rather the insect accommodates the chemical by altering one or more physiological functions. This may involve:

Reduced neuronal sensitivity to insecticides. Resistance due to kdr gene was found to be due to a recessive gene called $\mathrm{kdr}$ for "knockdown resistance". Also "super-kdr" is associated with pyrethroid resistance. The kdr factor confers resistance to DDT and pyrethroids through a target insensitivity mechanism. Two amino acid replacements associated with super-kdr trait are substitution of the leucine residue found at codon 1014 with either phenylalanine $(1014 \mathrm{~F})$ or serine $(1014 S)$ in the Voltage-Gated Sodium Channel and methionine at position 918 with threonine (M918T)

Altered target-site resistance (Altered acetylcholinesterase): The first indication that resistance might be associated with changes in acetylcholine esterase (AChE) was the observation that in organophosphate resistant mites, Tetranychus urticae, the affinity of AChE towards acetylcholine (ACh) was only one-third that of the susceptible counterpart. This has been documented in resistant strains of several insects natural enemies.
Decreased penetration of the insecticide through the body wall through the modification of the structure or composition of the cuticle eg. Additional waxy layers in resistant strains.

Increased excretion or sequestration of insecticides e.g. DDT storage in body fat, preventing it from reaching site of action.

\section{Role in IPM}

The use of naturally or artificially selected insecticide-resistant strains of natural enemies has been advocated to enhance the compatibility of biological and chemical controls.

The resistant strain of Trichogramma chilonis and other resistant natural enemies can be used as a component of bio-intensive IPM in various crops where insecticide use is higher.

Future pest management will depend strongly on biological control because it is the most sustainable, cheapest and environmentally safest system of pest management.

Use of tolerant strains of natural enemies is relatively permanent control method given no pesticidal interference.

It is a safe approach provided the proper preliminary research is conducted prior to natural enemy introductions and genetic improvement.

\section{References}

Agosin, M. 1985. Role of microsomal oxidations in insecticide degradation. Comparative Insect Physiology and Biochemistry 12, 647-712.

Charles, V., Puneeth, P., Vijayan, P.A and Jalali, S.K. 2011.Genetic aspects of insecticide tolerance in Trichogramma chilonis strains. Journal of Biological control.25:207-212

Coon, M. J., Vaz, A. D. and Bestervelt, L. L. 
1996. Peroxidative reactions of diversozymes. Federation of American Societies for Experimental Biology. 10: 428-434.

Dhaliwal, G.S., Jindal, V and Dhawan, A.K. (2010). Insect Pest Problems and Crop Losses: Changing Trends. Indian J.Ecol. 37: 1-7.

Frank, M. R. and Fogleman, J. C. 1992. Involvement of cytochrome P450 in host-plant utilization by Sonoran Desert Drosophila. Proceedings of National Academy Science USA 89, 11998-12 002.

Gould, F. 1984 Mixed function oxidases and herbivore polyphagy: the devil's advocate position. Ecological Entomology 9, 29-34.

Henry, C. S. 1979. Acoustical communication during courtship and mating in the green lacewing Chrysopa carnea (Neuroptera: Chrysopidae). Ann. Entomol. Soc. Am.72: 68-79.

Hitesh, N., Mitsunaga, T. and Mochizuki. A. 2005. Laboratory Hybridization Between the Introduced and the Indigenous Green Lacewings (Neuroptera: Chrysopidae: Chrysoperla) in Japan.. Environ. Entomol. 34(3): 727731

Hung, C. F., Prapaipong, H., Berenbaum, M. R. \& Schuler, M. A. 1995 Differential induction of cytochrome P450 transcripts in Papilio polyxenes by linear and angular furanocoumarins. Insect Biochemistry and Molecular Biology 25, 89-99.

Hoy, M. A. (1984). Genetic improvement of a biological control agent: multiple pesticide resistance and nondiapause in Metaseialus occidentalis (Nesbitt) (Phytoseiidae). Proceedings VI International Congress of Acarology, Edinburgh, 1982, Acarology VI, Volume 2. D. A. Griffiths and C. E. Bowman, editors, Ellis Horwood Ltd.,
Halsted Press, New York New York. pp.673-679.

Hoy, M.A. (1985). Recent advances in genetics and genetic improvement of the phytoseiidae. Annual review of Entomology. 30: 345-370.

IRAC database, 2010. www.irac.com Resistance Management for Sustainable Agriculture and Improved Public Health : Insecticide Resistance Action Commitee.

Jalali, S.K and Venkatesan, T. (2005). Annual report of the ICAR Cess Fund Project: development of a starain of Trichogramma chilonis Ishii tolerant to newer insecticides and high temperature. Project Directoriate of Biological Control, Bangalore, 45.

Jalali, S.K., Murthy, K.S., Venkatesan, T., Lalitha, Y. and Devi, P.S. 2006. Adaptive performance of Trichogramma chilonis Ishii. at low temperature. Annual Plant Protection Science. 14(1):5-7.

Neumann, E., Schaefer-Ridder,M.,Wang,Y. and Hofschneider,P.1982. Gene transfer into mouse lyoma cells by electroporation in high electric fields. EMBO J. 1(7): 841-845

Patel, I.S. and Yadav, D.N. 1995. Susceptibility of Amrasca biguttula and Chrysopa scelestes in cotton to three systemic insecticides. Indian journal of Agriculture Science, 65(4):308-309

Pielou,D.P and Glasser,R.F.1951. Selection for DDT tolerance in a beneficial parasite, macrocentrus ancylivorus roh.: i. some survival characteristics and the DDT resistance of the original laboratory stock. Canadian Journal of Zoology, 29(2): 90-101.

Presnail, J and Hoy, M.1992. Stable genetic transformation of a beneficial arthropod, Metaseiulus occidentalis (Acari: Phytoseiidae), by a microinjection technique. Proceedings of the National 
Academy of Sciences of the United States of America, 89(16) 7732-7736

Rao, V.P., Gandhi, M.A., Sankaran, T and Mathur, K.C. (1971). A review of the biological control of insects and other pests in South-east Asia and the Pacific regions; Common wealth Inst. Boil. Control. Tech. Commun. No. 6149 pp.

Roush, R.T and Hoy, M.A. (1981). Genetic improvement of Metaseiulus occidentalis: Selection with methomyl, dimethoate and carbaryl and genetic analysis of carbaryl resistance. Journal of Economic Entomology. 74: 138-141.

Routray, S., Det, D., Baral, s., Das, A and Mahantheshwara, B. 2016. Genetic improvement of natural enemies: A review. Agricultural Reviews. 37 (4) 325-332

Sankaran, T. (1986). Current status and future projections of biological control of insect pests in India. Proc. Indian natn Sci. Acad. 52: 108-116.

Spollen, M.K and Hoy, A.M.1992. Genetic improvement of an arthropod natural enemy: Relative fitness of a carbarylresistant strain of the California red scale parasite Aphytis melinus. Biological control. 2(2): 87-94

Tabashink, B.E., Mota Sanchez, D., Whalon, M.E., Hollingworth, R.M. and Carrlere, Y. 2014. Defining terms for proactive management of resistance to Bt crops and pesticides. Journal of economic entomology 107, 496-507.

Taylor, M. and Feyereisen, R. 1996. Molecular biology and evolution of resistance to toxicants. Molecular Biology and Evolution 13, 719-734.

Walker A.W. and Keasling, J.D. 2002. Metabolic engineering of Pseudomonas putida for the utilization of parathion as a carbon and energy source. Biotechnology of Bioeng. 78:715-721.

Zhang, M. and Scott, J. G. 1996. Purification and characterization of cytochrome b5 reductase from the house fly, Musca domestica. Comparative Biochemistry and Physiology 113: 175-183.

\section{How to cite this article:}

Shahida Ibrahim, Ramandeep Kour, Shalini Aryan and Nadeya Khaliq. 2020. Insecticide Resistant Natural Enemies and their Role in IPM. Int.J.Curr.Microbiol.App.Sci. 9(11): 36763693. doi: https://doi.org/10.20546/ijcmas.2020.911.442 